\title{
Garrison, Gary. (2018). Raising Grandkids: Inside Skipped-Generation Families. Regina: University of Regina Press.
}

\author{
Reviewed by: Eric Killeen, MacEwan University
}

In "Raising Grandkids", Gary Garrison takes a deep dive into the unique circumstances and challenges facing families in which children are being raised by their grandparents. Garrison calls these families skipped-generation families. Alongside some general discussion of the family dynamics common to these households, he provides in-depth portraits of several families. The biographies he sketches out are drawn from qualitative interviews he conducts with his fellow grandparents-cum-parents. Particular focus is given to Indigenous families, who are of course disproportionately dealing with family trauma and who are uniquely affected by the intergenerational trauma of family separation policies like residential schools and the lingering effects of colonization more broadly. There is also much focus on the developmental and behavioral challenges that children in skipped-generation families tend to present, including but not limited to Fetal Alcohol Spectrum Disorder, Attention Deficit Hyperactivity Disorder, and Oppositional Defiant Disorder.

The book is greatly strengthened by Garrison's intimate involvement with the subject matter. Not to say that a detached researcher with no firsthand lived experience cannot pen an indispensable account of a subject — they certainly can and often do — but the fact that Garrison himself is raising grandchildren provides him with invaluable insights that would no doubt be difficult or impossible to arrive at without that firsthand experience. It is also likely the case that 
it was easier for Garrison to get interview subjects to open up to him about their own lives raising their grandchildren knowing that they were speaking to a man going through many of the same experiences. As Garrison notes multiple times, many grandparents heading skipped-generation families can be somewhat secretive and closed off in discussing their lives because they fear that the government may break their family apart. It is largely for this reason that Garrison uses pseudonyms for the grandparents whose stories are recounted in the book; the grandchildren would have needed this treatment anyway given their tender ages. Knowing that the author was "one of them," so to speak, likely went a long way toward assuaging their fears and allowed them to be more forthcoming in their conversations.

Despite the often dark and dour subject matter intrinsic to the topic of families coping with trauma, the book is not all doom and gloom. Throughout the book, Garrison manages to inject some humor through his wit and self-deprecating ability to make light of his own difficult circumstances, such as when he quips, "What could be better than living with the woman I love and helping her raise her two grandchildren? If I'd found a woman to love who had no grandchildren in the house, of course, that would have been good too." (p. 12). Garrison quickly notes more seriously that seeing his partner take her grandchildren in made him love her even more, so it is not as though these occasional jokes detract from the serious subject matter. Later on in the book, Garrison jests about alien life observing life on Earth and "laughing at the insanity" of how readily we conceive children, including parents who likely would not be deserving of a parenting license were such a thing instituted (p. 168). This levity that he occasionally inserts helps to balance some of the darker passages of the book. 
It must be said that some of the stories included in the book are indeed difficult reading. There are stories of children being born with severe FASD because of their mothers' drinking habits while they were in the womb, as well as stories of heroin-addicted parents abandoning their children. Yet Garrison never descends into shaming and blaming parents who wind up in these kinds of circumstances: after all, addiction is an incredibly complicated thing, and no one expressly sets out to harm their children. Yes, individuals have free will, but our choices are always circumscribed by our conditions. Addicts are quite often dealing with trauma of their own, and Garrison does not go the easy route of blaming them.

In addition to these myriad stories of substance abuse and parental neglect, there are also stories of sexual abuse. It is not only the absent parents who have suffered indignities in life; the grandparents raising their grandchildren, too, have also been part of deeply troubled family dynamics. This trauma, one would imagine, reverberates across generations and is likely one factor in the difficulties the next generation faces. One grandmother who is now raising her grandchildren, identified as Tania, tells Garrison of her brother "forc[ing] her into the bushes by the creek and ma[king] her perform oral sex on him" when she was around thirteen years old (p. 107). Stories like this can be both triggering and infuriating for readers, and no one likes to be reminded that such things occur all too regularly in our society. It is easy to want to look away and put the book down, but Garrison has not included these stories gratuitously or in a remotely salacious manner. Rather, it is important that he be forthright about all the complicated family dynamics that often lead to skipped-generation families. As Garrison acknowledges from the earliest pages, grandparents do not simply raise their grandchildren because it seems like a fun 
way to spend their retirement years. While every family situation is different, the one constant is that some level of trauma has impacted each family, and for one reason or another the children's parents are unable or unwilling to provide an appropriate level of care. Grandparents step in out of an abundance of love, but without the initial trauma tearing at the seams of the nuclear family, their heroic caregiving would not be necessary.

The potential academic audience for this work would be quite latitudinous. Sociologists or anthropologists studying families and family forms, as well as psychologists studying children, families, or trauma would certainly be interested in "Raising Grandkids". Additionally, nearly any professional working with children, particularly at-risk children in clinical settings and the like, would benefit from this book. Child psychologists or psychiatrists, social workers, and pediatricians come to mind. Perhaps even lawyers specializing in family law who find themselves arguing custody cases might want to give this book a read to hone their understanding of family dynamics; Garrison reminds us just how litigious family situations can become when it comes to rehoming children. While acknowledging his "great admiration and sympathy for child welfare workers who take responsibility for society's most traumatized children and want to help horribly dysfunctional families," (p. xiv), Garrison notes that most parents/grandparents (including himself) are unable to trust the child welfare system and that it often leads to suboptimal outcomes for families who find themselves caught up in it. Still, a core part of the readership who could most benefit from reading this book would be those who are connected in some way or another to the aforementioned system. The book contains countless insights and while one would never want to generalize from one case to another given the unique circumstances of every family, surely 
"Raising Grandkids" would broaden caseworkers' understanding and frames of reference when it comes to working with families. It might even strengthen their ability to empathize with families in their caseload, given the strong emphasis on refraining from judgment and noting the difficult circumstances in which the various generations of many skipped-generation families find themselves.

Garrison's intention in writing this book seems to have been primarily twofold. First and most directly, he is contributing to the literature on an increasingly common but still underdiscussed family makeup, that of the skipped-generation family. Clearly, these types of families face some unique challenges that the average nuclear family does not have to contend with. It is equally clear that skipped-generation families will continue to be an important part of our social fabric going forward, so it is critical that greater attention is paid to them in terms of both academic research and government policy. Another, more subtle intention of Garrison's when writing the book was to help remove some of the stigma around grandparents raising grandchildren. It is undeniably true that this type of family faces a great deal of judgment from society at large. In painting a sympathetic, relatable portrait of them, Garrison has taken a great first step in eroding some of that stigma.

Garrison tries his utmost to show that despite the struggles that skipped-generation families face, the determination, resilience, and love that many grandparents show in raising grandchildren is a lesson in selfless caregiving worthy of tremendous admiration. Garrison does not merely provide a detached, clinical view of grandparents raising their grandchildren. Yes, the writing throughout is academic and professional, but Garrison makes clear that these individuals are 
putting an enormous amount of effort into providing their grandchildren with a loving home in which they can flourish despite the often difficult family circumstances that facilitated the emergence of their skipped-generation household in the first place. He is not afraid to stake his flag in the ground on the side of his subjects. After all, he is himself raising grandchildren. 